\title{
INTERNATIONAL FOOD STANDARDS AND WTO LAW
}

\author{
MARIELA MAIDANA-ELETtI*
}

Standards are used in all realms of human activity in order to specify the characteristics of a product, or its manufacture. In the process, they fulfil a range of functions, such as lowering risks, increasing trust and facilitating predictability in a given market. Standards reduce information costs for market players, which in turn allows for a more efficient functioning of the market. For international trade in foodstuffs, harmonisation of the wide variety of food standards is essential in order to facilitate the global foodsourcing trend. As traditional market access barriers are dismantled, nontariff measures offer a tool for the potential protection of domestic products, thus calling for effective forms of food governance. This article explores the legal implications of international standards under the TBT Agreement in the light of the WTO Appellate Body's case law. It further analyses the role played by international standard-setting organisations, such as the CAC and the ISO, in predicting the outcome of pending WTO disputes. Against this backdrop, this article also attempts to shed light on the current legal debate surrounding the use of private food standards within the SPS Committee.

\section{THE ROLE OF StANDARDS IN TRADE}

Standards are used in all realms of human activity in order to specify the characteristics of a product or its manufacture. In the process, they fulfil a range of functions, such as lowering risks, increasing trust and facilitating predictability in a given market. Hence, standard-setting aims to provide a

\footnotetext{
* LLM (Amsterdam), MLaw (Lucerne), BLaw (Madrid); PhD Candidate and Legal Researcher, Lucerne Law School, University of Lucerne, Switzerland and Visiting Research Fellow, World Trade Institute, University of Berne, Switzerland. For helpful comments on earlier drafts I am grateful to the editors and anonymous reviewers of Deakin Law Review. I gratefully acknowledge the financial support provided by the University of Lucerne and its Department of Public and Rural Law, under the aegis of Prof Dr iur Roland Norer. This study was completed during the autumn of 2014, when I was a Visiting Fellow at Deakin Law School, Deakin University. All opinions expressed here and any errors are my own.
} 
rational process to solve technical problems, based on science and governance. ${ }^{1}$ The existence of standards reduces information costs for market players, which in turn allows for a more efficient functioning of the market. ${ }^{2}$ For international trade in foodstuffs, the harmonisation of the wide variety of food standards is essential to facilitate the global food-sourcing trend. ${ }^{3}$ As traditional market access barriers are dismantled, non-tariff measures offer a tool for the protection of domestic products, thus calling for effective forms of food governance.

WTO law encourages, to varying extents, the design and adoption of international standards by imposing their use as a basis for regulation. This circumstance in turn creates a presumption of compliance with WTO rules that ultimately facilitates international trade. International standards thus act as a benchmark for better forms of governance while avoiding the adoption of tradedistorting measures and promoting harmonisation. This statement holds true particularly for trade in foodstuffs, given that compliance with food safety and quality standards will ultimately determine market access. Due to this favourable legal framework, however, the concept of an 'international standard' has been disputed. ${ }^{4}$ In order to clarify its legal meaning, the WTO Appellate Body designed a compliance test ${ }^{5}$ that allows for increased legal certainty.

${ }^{1}$ Governance is understood as the shift in allocation of authority from the top down, where all participating players in society pursue common goals through the exercise of control; cf Thomas A Loya and John Boli, 'Standardization in the World Policy: Technical Rationality over Power' in John Boli and George Thomas (eds), Constructing World Culture (Stanford University Press, 1999) 193; generally: Oran Young, International Governance: Protecting the Environment in a Stateless Society (Cornell University Press, 1994); Phillip Cerny, Globalization and the Changing Logic of Collective Action (1995) 49 (4) International Organizations 595-621.

2 Steve Charnovitz, 'International Standards and the WTO' (Public Law and Legal Theory Working Paper No 133, The George Washington University Law School, 2002) 12.

${ }^{3}$ Linda Fulponi, 'Private Voluntary Standards in the Food System: The Perspective of Major Food Retailers in OECD Countries' (2006) 31 Food Policy 1-13.

${ }^{4}$ Appellate Body Report, European Communities - Trade Description of Sardines, WTO Doc WT/DS231/AB/R (26 September 2002) ('EC-Sardines'); Appellate Body Report, United States - Measures Concerning the Importation, Marketing and Sale of Tuna and Tuna Products, WTO Doc WT/DS381/AB/R (16 May 2012) ('US - Tuna II (Mexico)'); Appellate Body Report, United States - Measures Affecting the Production and Sale of Clove Cigarettes, WTO Doc WT/DS406/AB/R (4 April 2012) ('US - Clove Cigarettes'); Appellate Body Report, United States - Certain Country of Origin Labelling (COOL) Requirements, WTO Doc $W T / D S 384 / 386 / A B / R$ (29 June 2012) ('US - COOL').

${ }^{5}$ Panel Report, United States - Measures Concerning the Importation, Marketing and Sale of Tuna and Tuna Products, WTO Doc WT/DS381/R (15 September 2011) [7.627]. 
Hence, this article explores the relevance of food standards in international trade. In doing so, it examines the legal standing of international standards in determining compliance with the law of the World Trade Organisation (WTO) ${ }^{6}$ in general and its Agreement on Technical Barriers to Trade (TBT Agreement) ${ }^{7}$ in particular. It also explores the role played by international standard-setting organisations as de facto regulators and analyses the current dilemma involving the legal classification of private food standards in international trade.

\section{INTERNATIONAL STANDARDS UNDER WTO LAW}

\section{A The TBT Agreement: The Three-Step Test}

The TBT Agreement recognises the importance of international standards for international trade and therefore imposes upon Members the obligation to use international standards as the foundation for regulatory practices, while leaving a margin of discretion as to the choice of measure and its use. ${ }^{8}$ The relevant provision is found in Article 2.4 of the TBT Agreement. It reads:

Where technical regulations are required and relevant international standards exist or their completion is imminent, Members shall use them, or the relevant parts of them, as a basis for their technical regulations except when such international standards or relevant parts would be an ineffective or inappropriate means for the fulfilment of the legitimate objectives pursued, for instance because of fundamental climatic or geographical factors or fundamental technological problems. ${ }^{9}$

This provision was called upon in four disputes that have been adjudicated within the WTO Dispute Settlement System. ${ }^{10}$ Based on this jurisprudence, a

\footnotetext{
${ }^{6}$ Marrakesh Agreement Establishing the World Trade Organisation, opened for signature 15 April 1994, 1867 UNTS 3 (entered into force 1 January 1995) ('Marrakesh Agreement').

${ }^{7}$ Ibid annex 1A ('Multilateral Agreements on Trade in Goods').

${ }^{8}$ Cf Erik Wijkstrom and Devin McDaniels, 'International Standards and the WTO TBT Agreement: Improving Governance for Regulatory Alignment' (Staff Working Paper ERSD, World Trade Organization, 2013) 3.

${ }^{9}$ Agreement on Technical Barriers to Trade, opened for signature 12 April 1979, 1186 UNTS 276 (entered into force 1 January 1980) art 2.4.

${ }^{10}$ Appellate Body Report, European Communities - Trade Description of Sardines, WTO Doc WT/DS231/AB/R (26 September 2002); Appellate Body Report, United States - Measures Concerning the Importation, Marketing and Sale of Tuna and Tuna Products, WTO Doc WT/DS381/AB/R (16 May 2012); Appellate Body Report, United States - Certain Country of Origin Labelling (COOL) Requirements, WTO Doc WT/DS384/386/AB/R (29 June 2012).
} 
three-step test ${ }^{11}$ was established to determine compliance with Article 2.4 of the TBT Agreement. As a result, for a measure to be in compliance with Article 2.4 of the TBT Agreement, the respondent party must demonstrate that the regulation at stake was based on an international standard. This will be so in cases where the regulation a) used a relevant international standard b) as its basis and the standard is c) appropriate to and effective in the attainment of a legitimate aim.

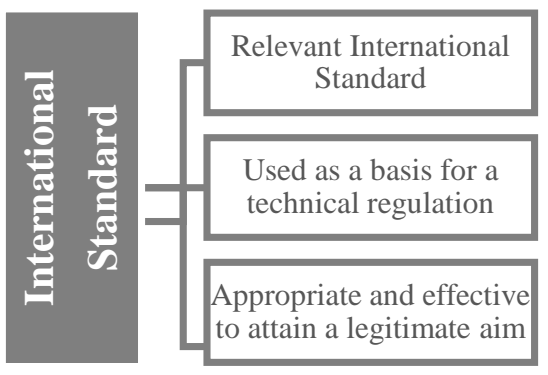

Figure 1: WTO Minimum Standard of Review for International Standards

Source: Panel Report, US - Tuna II (Mexico), [7.627].

As the above figure shows, the identified compliance test for Article 2.4 of the TBT Agreement requires the completion of three steps to establish a nonviolation of the TBT Agreement. These steps will be discussed in detail as follows.

\section{The Relevant International Standard}

The WTO Appellate Body first addressed the concept of 'relevant' international standards in EC - Sardines. ${ }^{12}$ In that case, a European regulation controlling the labelling and marketing requirements of preserved sardines was challenged by Peru under Article 2.4 of the TBT Agreement. This measure allowed for the marketing and labelling of products prepared from a specific (European)

\footnotetext{
${ }^{11}$ Panel Report, United States - Measures Concerning the Importation, Marketing and Sale of Tuna and Tuna Products, WTO Doc WT/DS381/R (15 September 2011) [7.627].

12 Appellate Body Report, European Communities - Trade Description of Sardines, WTO Doc WT/DS231/AB/R (26 September 2002).
} 
species of sardines ${ }^{13}$ to the exclusion of products prepared from other (Peruvian) species of sardines. ${ }^{14}$

The WTO Appellate Body based its findings on an analysis of the 'relevance' of an international standard for canned sardines and sardine-type products in the light of the standard Codex Stan 94, drafted by the Codex Alimentarius Commission. ${ }^{15}$ Concurring with the conclusion reached by the WTO Panel Report, ${ }^{16}$ the Appellate Body held that the ordinary meaning of the term 'relevant' is 'bearing upon or relating to the matter in hand; pertinent' ${ }^{17}$

It then followed that, in the case at hand, for Codex Stan 94 to be a relevant international standard, it had to bear upon, relate to, or be pertinent to the EC regulation challenged. ${ }^{18}$ Because the challenged measure dealt with the same product as the Codex Stan 94 and included the provisions set out in the Codex Stan 94, it was found that the CAC standard in question provided sufficient basis to be considered a 'relevant international standard' in that case. ${ }^{19}$

This reasoning was upheld in US - Tuna II (Mexico), where Mexico challenged a US regulation establishing the conditions for use of a 'dolphin-safe' label on tuna products. The Appellate Body was called upon to assess whether the dolphin-safe definition and certification standards defined by the Agreement on International Dolphin Conservation Program (AIDCO), which establish dolphin mortality limits, specific fishing techniques, and fishing gear to reduce dolphin by-catch, constituted a relevant international standard.

In that case, however, the 'relevant international standard' for the purposes of the TBT Agreement was identified in accordance with the characteristics of the standard-setting body. Based on an interpretation of the definition of 'standard'

\footnotetext{
${ }^{13}$ The European Sardina Pichardus.

${ }^{14}$ The Peruvian Sardinops Sagax.

15 Codex Alimentarius Commission [CAC] as established by the Joint FAO/WHO Conference on Food Standards, ALINORM 62/8 (1-5 October 1962).

16 Panel Report, European Communities - Trade Description of Sardines, WTO Doc WT/DS231/R (29 May 2002) [7.68], quoting Webster's New World Dictionary (William Collins \& World Publishing Co, Inc, 1976) 1199.

${ }^{17}$ Appellate Body Report, European Communities - Trade Description of Sardines, WTO Doc WT/DS231/AB/R (26 September 2002) [231]-[232].

18 Panel Report, European Communities - Trade Description of Sardines, WTO Doc WT/DS231/R (29 May 2002) [7.68].

19 Panel Report, European Communities - Trade Description of Sardines, WTO Doc WT/DS231/R (29 May 2002) [7.69].
} 
set out in Annex 1 of the TBT Agreement ${ }^{20}$ and its explanatory note, ${ }^{21}$ the Appellate Body stated that an international standardising body is 'a body that has recognised activities in standardisation and whose membership is open to the relevant bodies of all WTO Members' ${ }^{22}$ It further elaborated on the concept of, and set out three requirements for, membership openness: there should be (i) no restrictions on membership by WTO members; ${ }^{23}$ (ii) automatic accession; ${ }^{24}$ and (iii) openness at all stages of standard development, to be decided on a case-by-case basis. ${ }^{25}$ After carrying out a legal assessment, the Appellate Body concluded that AIDCO standards could not be deemed as 'relevant international standards' for the purposes of Article 2.4 of the TBT Agreement. ${ }^{26}$ The organisation did not qualify as an 'international standardisation body' because accession was by invitation only, which in turn had to be extended by consensus among Members. Hence, the membership openness requirement, which imposes a prohibition on the restriction of membership by WTO members, was not fulfilled by AIDCO, leading to the violation of Article 2.4 of the TBT Agreement.

Another case addressing the importance of the relevant international standard was US - Clove Cigarettes. ${ }^{27}$ In this case, Indonesia challenged a US measure banning the production and sale of cigarettes with flavours other than tobacco or menthol. Although the challenge was not brought under Article 2.4 of the TBT Agreement, ${ }^{28}$ the Panel stated that it was aware of the existence of international standards to curb smoking within the WHO Framework

${ }^{20}$ According to which a standard is: '[a] [d] ocument approved by a recognized body, that provides, for common and repeated use, rules, guidelines or characteristics for products or related processes and production methods, with which compliance is not mandatory. It may also include or deal exclusively with terminology, symbols, packaging, marking or labelling requirements as they apply to a product, process or production method': Agreement on Technical Barriers to Trade, opened for signature 12 April 1979, 1186 UNTS 276 (entered into force 1 January 1980) Annex 1, para 2.

${ }^{21}$ Ibid, whereby 'standards are defined as voluntary (...) documents. Standards prepared by the international standardization community are based on consensus.'

${ }^{22}$ Appellate Body Report, United States - Measures Concerning the Importation, Marketing and Sale of Tuna and Tuna Products, WTO Doc WT/DS381/AB/R (16 May 2012) [359].

${ }^{23}$ Ibid [364].

${ }^{24}$ Ibid [386].

${ }^{25}$ Ibid [374].

${ }^{26}$ Ibid [401].

${ }^{27}$ Appellate Body Report, United States - Measures Affecting the Production and Sale of Clove Cigarettes, WTO Doc WT/DS406/AB/R (4 April 2012).

${ }^{28}$ Panel Report, United States - Measures Affecting the Production and Sale of Clove Cigarettes, WTO Doc WT/DS406/R (4 April 2012) [7.496]. 
Convention on Tobacco Control. ${ }^{29}$ The fact that the Panel decided to mention its awareness of international standardisation tendencies, even though no formal challenge had been brought against a measure based on an international standard, demonstrates once again the relevance of the standardisation process at the global level.

\section{International Standards as a Basis for Regulation}

The question of whether a relevant international standard has been used as a basis for regulation was addressed in EC - Sardines. ${ }^{30}$ In that case, the Appellate Body agreed with the Panel that an international standard is used 'as a basis for ${ }^{31}$ a technical regulation when it is used as a principal constituent, or fundamental principle, in enacting that technical regulation. It further stated that there must be a 'very strong and very close relationship' ${ }^{32}$ between the challenged measure and the invoked international standard for the latter to constitute a basis for the former.

The Appellate Body continued to lay down, as the minimum standard of connection between the measure and the standard, the lack of contradiction between them. In the words of the Appellate Body:

[I]t can certainly be said — at a minimum - that something cannot be considered a "basis" for something else if the two are contradictory. Therefore, under Article 2.4, if the technical regulation and the international standard contradict each other, it cannot properly be concluded that the international standard has been used "as a basis for" the technical regulation. ${ }^{33}$

While construing this interpretation, the Appellate Body deemed it relevant to refer to its approach in interpreting the term 'based on' in the context of Article 3.1 of the SPS Agreement. ${ }^{34}$ This provision establishes a presumption of compliance with the SPS Agreement, in cases where the challenged measure is based on international (food) standards, designed and adopted by the CAC.

\footnotetext{
${ }^{29}$ WHO Framework Convention on Tobacco Control, opened for signature 21 May 2003, 2302 UNTS 116 (entered into force 27 February 2005).

${ }^{30}$ Appellate Body Report, European Communities - Trade Description of Sardines, WTO Doc WT/DS231/AB/R (26 September 2002).

31 Ibid [240]-[244].

${ }^{32}$ Ibid [245].

${ }^{33}$ Ibid [248].

${ }^{34}$ Ibid [242].
} 
Following this line, the TBT Agreement and its interpretative jurisprudence lend themselves to establish a presumption of compliance, whereby technical regulations are presumed not to be trade-distorting if adopted in accordance with a relevant international standard. ${ }^{35}$ In contrast to the SPS Agreement, however, where reference is made to specific standard-setting bodies, the TBT Agreement offers a greater margin of discretion in choosing the relevant international standardisation body and its standards as a basis for a WTO compliant measure.

\section{Effectiveness and Appropriateness in Attaining a Legitimate Aim}

The implicit obligations of WTO Members to base their TBT measures on relevant international standards can be avoided only in cases where their use would lead to a level of protection which is inappropriate to, or ineffective in, the fulfilment of their legitimate objectives.

To determine the concept of 'effectiveness', the Appellate Body upheld the interpretation given by the Panel in EC - Sardines, whereby the term 'ineffective' refers to something that does not have the 'function of accomplishing' or have 'a result' or something that is not 'brought to bear'; 36 and the term 'inappropriate' refers to something that is not 'specially suitable', 'proper' or 'fitting' for the achievement of a legitimate objective. ${ }^{37}$ The Appellate Body further agreed on the statement made by the Panel that these two terms have different meanings, stating that 'it is conceptually possible that a measure could be effective but inappropriate, or appropriate but ineffective'. ${ }^{38}$ In other words, both requirements must be cumulatively fulfilled for a measure to be compliant with Article 2.4 of the TBT Agreement. Later, the Panel Report on US - Tuna II (Mexico) recalled this precedence while establishing that Mexico bore the burden of showing that the AIDCP standard is both effective and appropriate. ${ }^{39}$

\footnotetext{
${ }^{35}$ Wijkstrom and McDaniels, above n 8, 14.

36 Panel Report, European Communities - Trade Description of Sardines, WTO Doc WT/DS231/R (29 May 2002) [7.116].

${ }^{37}$ Ibid.

${ }^{38}$ Appellate Body Report, European Communities - Trade Description of Sardines, WTO Doc WT/DS231/AB/R (26 September 2002) [289].

${ }^{39}$ Panel Report, United States - Measures Concerning the Importation, Marketing and Sale of Tuna and Tuna Products, WTO Doc WT/DS381/R (15 September 2011) [7.725].
} 
In US - COOL ${ }^{40}$ the Appellate Body defined the concept of 'legitimate objectives' while assessing whether certain US requirements for labelling meat products were in compliance with TBT obligations. In that case, it acknowledged the legitimacy of a US measure requiring the disclosure of country of origin information in the labelling of meat products, the disclosure being intended to inform consumers 'on the countries in which the livestock from which the meat they purchase is produced were born, raised and slaughtered' ${ }^{41}$ However, the costs associated with the implementation of that measure, a measure which did not necessarily translate into additional information being provided to consumers, would de facto lead to an exclusive use of domestic livestock by US producers and 'thus [had] a detrimental impact on the competitive opportunities of imported livestock' ${ }^{42}$ Hence, an approach is necessary which balances the sovereign right of WTO members to adopt domestic measures against their right to trade in another WTO member's market.

\section{INTERNATIONAL StANDARD-SETTING ORganisations}

The previous section showed that standard-setting organisations with international dimensions, such as the Codex Alimentarius Commission (CAC), play a fundamental role in providing the tools for assessing the WTO compatibility of domestic regulation. This holds true for food safety and quality standards as well. While the CAC is the leading standard-setting body for food safety, the International Organisation for Standardization (ISO), with its comprehensive set of standards, has also acquired an important role in the regulation of food quality. Although there exist other relevant standard-setting organisations with their own internal dispute settlement mechanisms ${ }^{43}$ for animal health and zoonoses ${ }^{44}$ as well as for plant health, ${ }^{45}$ this part will not deal with them. ${ }^{46}$

40 Appellate Body Report, United States - Certain Country of Origin Labelling (COOL) Requirements, WTO Doc WT/DS384/386/AB/R (29 June 2012).

${ }^{41}$ Ibid [453].

42 Ibid [349].

43 Marina Foltea, International Organizations in WTO Dispute Settlement: How Much Sensitivity? (Cambridge University Press, 2012) 157.

${ }^{44}$ Such as the International Office of Epizootics [OIE].

${ }^{45}$ Such as the International Plant Protection Convention [IPPC].

${ }^{46}$ For a short overview of the IPPC and the OIE see Terence Stewart and David Johanson, 'The SPS Agreement of the World Trade Organisation and Interntional Organisations: The Roles of the Codex Alimentarius Commission, the International Plant Protection Convention and the International Office of Epizootics' (1998) 26 Syracuse Journal of International Law 27. 
In spite of their voluntary nature, the standards designed by relevant international standard-setting bodies have achieved a high and sometimes disputed legal status. This is due in some instances to their explicit mention in WTO instruments - as is the case with the CAC in the SPS Agreement ${ }^{47}-$ and in other instances to their use in agreement interpretation by the WTO dispute settlement system, as is the case with ISO standards. ${ }^{48}$ Hence, this part aims at analysing the legal mechanisms of the CAC and the ISO, addressing their rules of procedure, development and adoption of standards.

\section{A Codex Alimentarius Commission}

\section{The Objectives and Nature of the CAC}

The Codex Alimentarius Commission is the most influential food standardsetting body at the international level. ${ }^{49}$ Its main objective is to set international food standards for the protection of public health and the promotion of fair practice in food trade. ${ }^{50}$ Unlike more recent WTO instruments, the CAC was established in 1962 by the Joint FAO/WHO Food Standards Programme as their subsidiary body to respond to the increased trade in food. ${ }^{51}$ It elaborates on international standards, codes of practice, guidelines and related texts addressing food safety and quality with a view to facilitating international trade. ${ }^{52}$ For many decades, the legal relevance of CAC standards was dismissed because of their non-binding nature, and merely advisory role. ${ }^{53}$ It was only

\footnotetext{
${ }^{47}$ Agreement on Sanitary and Phytosanitary Measures, opened for signature 15 April 1994, 1867 UNTS 493 (entered into force 1 January 1995) annex A.

${ }^{48}$ Cf Appellate Body Report, European Communities - Trade Description of Sardines, WTO Doc WT/DS231/AB/R (26 September 2002) and Appellate Body Report, United States Measures Concerning the Importation, Marketing and Sale of Tuna and Tuna Products, WTO Doc WT/DS381/AB/R (16 May 2012).

${ }^{49}$ Other international institutions also devote their work to setting standards in the area of food safety, eg, the Organisation for Economic Cooperation and Development (OECD).

50 CAC Procedural Manual (World Health Organization and the Food and Agriculture Organization of the United Nations, 19th ed, 2010) ('CAC Procedural Manual') arts 1(c), (d) and (e),

${ }^{51}$ As a subsidiary organ, the CAC depends financially and institutionally on the FAO and the WHO, a dependence which impairs its ability to rapidly and effectively adopt standards.

${ }^{52}$ CAC, Understanding the Codex Alimentarius (World Health Organization and the Food and Agriculture Organization of the United Nations, 3rd ed, 2006).

53 Prior to the adoption of the SPS Agreement, CAC standards were binding only when voluntarily transposed into national legislation and thus they remained untouched by national or international political interests. See generally: Matthias Herdegen, 'Biotechnology and Regulatory Risk Assessment' in George Bermann, Matthias Herdegen and Peter Lindseth (eds), Transatlantic Regulatory Cooperation: Legal Problems and Political Prospects (Oxford
} 
upon the adoption of the WTO Agreements that the Codex Alimentarius was upgraded to semi-binding status. ${ }^{54}$ The SPS Agreement in its Articles $3.4^{55}$ and $12.3^{56}$ explicitly refers to the adoption of the CAC standards as a way to sustain a presumption of compliance with food safety rules.

Whether the CAC standards are binding in nature has been intensely debated among legal scholars, without consensus being reached. ${ }^{57}$ The findings of the WTO Appellate Body in EC - Hormones ${ }^{58}$ explicitly rejected the argument that international standards should be accorded binding force. It stated:

We cannot lightly assume that sovereign states intended to impose upon themselves the more onerous, rather than the less burdensome, obligation by mandating conformity or compliance with such [international] standards (...).To sustain such an assumption and to warrant such a far-reaching interpretation, treaty language far more specific and compelling than that found in Article 3 of the SPS Agreement would be necessary. ${ }^{59}$

Fifteen years after these findings, the de facto binding nature of CAC standards still continues to be questioned. ${ }^{60}$ It has even prompted debate on the legitimacy

University Press, 2001) 301-17; Frode Veggeland and Svein Borgen, Changing the Codex: The Role of International Institutions (Norwegian Agricultural Economics Research Institute, 2002).

${ }^{54}$ Cf Alessandra Arcuri, The Coproduction of the Global Regulatory Regime for Food Safety Standards and the Limits of a Technocratic Ethos (RSCAS Working Paper, European University Institute 2014/97) 3; Veggeland and Svein Ole Borgen, 'Negotiating International Food Standards: The World Trade Organisation's Impact on the Codex Alimentarius Commission' (2005) 18(4) Governance 675-708.

${ }^{55}$ Art 3.4 of the SPS Agreement reads: 'Members shall play a full part, within the limits of their resources, in the relevant international organizations and their subsidiary bodies, in particular the Codex Alimentarius Commission ... to promote within these organizations the development and periodic review of standards, guidelines and recommendations with respect to all aspects of sanitary and phytosanitary measures.'

${ }^{56}$ Art 12.3 of the SPS Agreement reads: 'The Committee shall maintain close contact with the relevant international organizations in the field of sanitary and phytosanitary protection, especially with the Codex Alimentarius Commission ... with the objective of securing the best available scientific and technical advice for the administration of this Agreement.'

${ }^{57}$ Rejecting the binding nature of CAC standards, see Joanne Scott, 'International Trade and Environmental Governance: Relating Rules (and Standards) in the EU and the WTO', (2004) 15(2) European Journal of International Law 307-54; Reinhard Quick and Andreas Blunther, 'Has the Appellate Body Erred? An Appraisal and Criticism of the Ruling in the WTO Hormones Case' (1999) 2(4) Journal of International Economic Law 603-39.

${ }^{58}$ Appellate Body Report, European Communities - Measures Concerning Meat and Meat Products, WTO Doc WT/DS26/AB/R (16 January 1998) ('EC-Hormones') [162]-[165].

${ }^{59}$ Ibid [165].

${ }^{60}$ Illustrating the current discussion on the binding force of CAC standards, see Marielle Matthee, 'The Codex Alimentarius Commission and its Food Safety Measures in the Light of their New 
and transparency of the adoption process used by the CAC ${ }^{61}$ In particular, it is asked whether the lengthy adoption process and the rapid development of new technologies affecting food production are hindering the harmonisation task with which this institution has been entrusted. ${ }^{62}$

As shown in recent WTO case law, however, concerns about procedural transparency and legitimacy should not distract from the semi-binding nature of CAC standards. A joint analysis of EC - Hormones, ${ }^{63}$ which specifically rejected the binding nature of CAC standards in the context of the SPS Agreement, and of the compliance test designed by the Appellate Body in EC - Sardines ${ }^{64}$ for the TBT Agreement leads to the conclusion that WTO law provides legal flexibilities in its provisions sufficient to allow CAC standards to create a prima facie presumption of compliance with WTO obligations.

\section{The CAC Rules of Procedure}

CAC Membership is open to all WHO and FAO Members. It is led by an executive committee, consisting of the Chair of the Commission, three Vicechairs, Coordinators appointed by the Commission for certain regions or group of countries, and seven members, one each for Africa, Asia, Europe, the Near East, North America, the South-West Pacific, and Latin America and the

Status' in Michelle Everson and Ellen Vos (eds), Uncertain Risks Regulated, (Routledge Cavendish Publishing, 2009) 325-9.

61 The legitimacy of the CAC to adopt international standards remains questioned. See inter alia: Henrik Horn and Joseph Weiler, 'European Communities - Trade Description of Sardines: Textualism and its Discontent' in Henrik Horn and Petros Mavroidis (eds), The WTO Case Law of 2002 (Cambridge University Press, 2005) 248-75; Sidney Shapiro, 'International Trade Agreements, Regulatory Protection and Public Accountability' (2002) 54(1) Administrative Law Review 435-57. Likewise, transparency concerns are still being discussed among CAC Members. See, inter alia, CAC (FAO/WHO Food Standards Programme), Report of the TwentySecond Session of the Codex Committee on General Principles, ALINORM 05/28/33A (11-15 April 2005) [98]-[105]; CAC (FAO/WHO Food Standards Programme), Report of the Nineteenth (Extraordinary) Session of the Codex Committee on General Principles, ALINORM 04/27/33 (17-21 November 2003) [40]-[45].

${ }^{62}$ Regretting the increased politicisation of internal mechanisms of standard adoption, see Alberto Alemanno, Trade in Food: Regulatory and Judicial Approaches in the EC and the WTO (Cameron May Publishing, 2007) 273-4 ('Alemanno').

${ }^{63}$ Appellate Body Report, European Communities - Measures Concerning Meat and Meat Products, WTO Doc WT/DS26/AB/R (16 January 1998) ('EC-Hormones').

${ }^{64}$ Also, Appellate Body Report, United States - Measures Concerning the Importation, Marketing and Sale of Tuna and Tuna Products, WTO Doc WT/DS381/AB/R (16 May 2012); Appellate Body Report, United States - Measures Affecting the Production and Sale of Clove Cigarettes, WTO Doc WT/DS406/AB/R (4 April 2012). 
Caribbean. The Executive Committee meets annually as well as before each Commission session. ${ }^{65}$

The CAC Secretariat is based in Rome, at FAO headquarters. It provides administrative support for the organisation of the sessions and the coordination of the work carried out by subsidiary bodies to the Codex. ${ }^{66}$ The CAC functions according to its Procedural Manual, which is composed of the Codex Statutes and the Rules of Procedure. The Manual sets up rules for membership, the appointment and responsibilities of officers, the frequency and operation of Codex sessions, voting procedure, and the preparation of records, reports and budget allocations. ${ }^{67}$

In practice decisions are adopted by consensus, although de jure the Rules of Procedure require that they be carried by a majority of votes. Senior officials appointed by their respective governments form the delegations that represent each Member State, which has one vote. Observers, and those granted observer status (such as representatives of the industry, consumer associations and international academic institutes) are allowed to participate in the decisionmaking process, without a vote.

\section{The Development of CAC Standards}

The standards developed by the CAC address processed, semi-processed and raw food. They also contain numerous maximum residue limits for pesticides in foods and animal feed, residue levels for veterinary drugs in foods of animal origin, and acceptable levels of food additives and contaminants. ${ }^{68}$ The preparation of these standards takes place in Codex Committees. These Committees are of two types: Commodity Committees and General Subject Committees.

Commodity Committees develop vertical standards on food quality. Their subject matter includes fresh fruit and vegetables, processed meat and poultry products. Some of these Committees have already completed their work and are now inactive for an unspecified period of time, while others are kept active

${ }^{65}$ CAC, Understanding the Codex Alimentarius, above n 52, 15; Jessica Vapnek and Melvin Spreij, Perspectives and Guidelines on Food Legislation: With a New Model Food Law (Food and Agriculture Organisation, 2005) 30.

${ }^{66}$ CAC, Understanding the Codex Alimentarius, above n 52, 19; Vapnek and Spreij, above n 65, 31.

${ }^{67}$ CAC, Understanding the Codex Alimentarius, above n 52, 14; Vapnek and Spreij, above n 65, 30.

${ }^{68}$ CAC, Understanding the Codex Alimentarius, above n 52, 11; Vapnek and Spreij, above n 65, 31. 
to review and align standards with current practice. This in turn has resulted in a loss of prominence for Commodity Committees in favour of the General Subjects Committees which develop horizontal safety standards. ${ }^{69}$ General Subjects Committees develop principles applicable horizontally to all, or a specific group of, food products, while developing recommendations on consumer health and safety. These Committees generally rely on independent expert advice to design and develop food standards. ${ }^{70}$

\section{The Adoption of CAC Standards}

The CAC develops and adopts standards according to its strategic six-year plan, which acts as a benchmark for submitted individual proposals. The strategic plan is reviewed every two years in order to adjust to current demands. The Executive Committee critically reviews new proposals for standards in order to ensure their development within a reasonable period of time, based on the requirements and availability of expert scientific advice. This decision-making process represents collective policy action and multilateral cooperation through the joint activities of the FAO and WHO, which ultimately aim at attaining high levels of consumer protection, public health and food safety. ${ }^{71}$ With a view to making the adoption of Codex standards more inclusive, transparent and, ultimately, more effective, a joint FAO/WHO/CAC evaluation was carried out in 2002. As a result of this, the Codex Commission adopted several amendments to its rules of procedure. ${ }^{72}$

The number of international food standards, guidelines and recommendations adopted by the CAC that have been implemented in domestic legislation has dramatically increased. This change is due mainly to two interrelated factors. On the one hand it results from the recognition of the Codex Alimentarius as the main source of food safety standards in the SPS Agreement. ${ }^{73}$ On the other hand, the Codex Alimentarius gained importance by being indirectly recognised as an international standard-setting organisation by the TBT

${ }^{69}$ CAC, Understanding the Codex Alimentarius, above n 52, 17-18; Vapnek and Spreij, above n 65, 33.

${ }^{70}$ CAC, Understanding The Codex Alimentarius, above n 52, 17-18; Vapnek and Spreij, above n 65, 30.

${ }^{71}$ World Health Organization, Global Strategy for Food Safety (2002) <http://whqlibdoc.who. int/publications/9241545747.pdf>.

${ }^{72}$ CAC (FAO/WHO Food Standards Programme), Report of the Twenty-Eighth Session of the Codex Committee on Processed Fruits and Vegetables, ALINORM 05/28/27 (4 to 9 July 2005).

${ }^{73}$ See Department of Foreign Affairs and Trade, Thailand-Australia Free Trade Agreement Chapter 6, 'Food Safety Standards as Sanitary and Phytosanitary Measures' (no date) $<$ http://www.dfat.gov.au/fta/tafta/tafta_chapter_6.html>. 
Agreement. ${ }^{74}$ The resulting reinforcement of legitimacy is tangible. Whereas the first thirty years of the Codex's existence were characterised by the adoption of standards largely implemented in developing countries seeking access to major markets, the last decade saw a significant increase in the Codex's profile among developed countries. ${ }^{75}$ Ultimately, it is the promotion of policy cooperation and regulatory harmonisation ${ }^{76}$ required to overcome global trade barriers that underlies the success of the CAC.

\section{B The International Standardization Organization}

The ISO was created during a conference at the Institute of Civil Engineers in London in 1946 to facilitate the international coordination and unification of industrial standards. ${ }^{77}$ It was the result of combining two already existing standard-setting organizations: ${ }^{78}$ the International Federation of the National Standardizing Associations (ISA) ${ }^{79}$ and the United Nations Standards Coordinating Committee (UNSCC) ${ }^{80}$ The main objective of the ISO is to promote the development of standardisation worldwide, and so facilitate the international exchange of goods. ${ }^{81}$

\section{ISO Membership}

Unlike the CAC, the ISO is a non-governmental organisation with members from 162 countries, which draw solely from their respective national standards

\footnotetext{
${ }^{74}$ Annex A to the TBT Agreement; Appellate Body Report, European Communities - Trade Description of Sardines, WTO Doc WT/DS231/AB/R (26 September 2002) [221].

75 Michael Livermore, 'Authority and Legitimacy in Global Governance: Deliberation, Institutional Differentiation and the Codex Alimentarius' (2006) 81 New York University Law Review 766.

${ }^{76}$ CAC (FAO/WHO Food Standards Programme), Report of the Twenty-Third Session of the Codex Committee on Methods of Analysis and Sampling, ALINORM 01/23 (2-7 July 2001) [12].

${ }^{77}$ Vapnek and Spreij, above n 65, 44.

${ }^{78}$ International Organization for Standardization, Friendship among Equals: Recollection from ISO’s First Fifty Years (ISO, 1997) 15.

${ }^{79}$ The International Federation of the National Standardizing Associations (ISA) was created in New York in 1926.

${ }^{80}$ The United Nations Standards Coordinating Committee (UNSCC) was created in London in 1944.

81 International Organization for Standardization, ISO Statutes (2013) <http://www. iso.org/iso/statutes.pdf $>$, 2.1.
} 
bodies. ${ }^{82}$ Members can delegate their rights and obligations to other organisations, but they remain responsible to the other members. ${ }^{83}$ However, membership is limited to one institution (private or public) per country; ${ }^{84}$ whichever represents the standardisation practices of that country best. The ISO has three types of membership: full member bodies, correspondent members and subscriber members. These member categories enjoy different levels of access and influence over the ISO system. The type of membership that a country has is determined by its Gross National Income and trade figures, factors which also determine the fees that it is called upon to pay. ${ }^{85}$

ISO Members meet annually at a General Assembly, which deals with proposals from the ISO Council, which in turn meets twice a year. The membership of the ISO Council is based on a yearly rotation to ensure an even representation of all the ISO members. Operational matters related to the dayto-day functioning of the organisation are dealt with by a permanent SecretaryGeneral reporting to the ISO President, whose term lasts two years.

\section{The Development and Adoption of ISO Standards}

The ISO develops new standards on the basis of proposals by its Members during the General Assembly. ${ }^{86}$ Once a proposal is adopted, the relevant Technical Committee, composed of experts from industrial, business and technical sectors and put forward by ISO members, develops the required standard. The ISO has over 250 technical committees, all of them answering to three additional General Policy Development Committees. ${ }^{87}$

ISO standards are entirely voluntary in nature. Due to high levels of implementation in national legal systems, however, they are invested with a de

\footnotetext{
82 Ibid 3.3. The recent, 2012, modification in ISO membership rules reflects a much-needed change in internal policy, whereby no bodies other than the national standard bodies may be eligible for ISO membership.

${ }^{83}$ International Organization for Standardization, ISO Membership Manual (August 2013) $<$ http://www.iso.org/iso/iso_membership_manual_2013.pdf>, 17.

${ }^{84}$ International Organization for Standardization, Friendship among Equals: Recollection from ISO's First Fifty Years (ISO, 1997) 3.2.

${ }^{85}$ International Organization for Standardization, ISO, Structure and Governance (no date) $<$ http://www.iso.org/iso/home/about/about_governance.htm>.

${ }^{86}$ The ISO standard-setting process available on the Internet addresses only six, instead of eight, steps: International Organization for Standardization, Developing ISO Standards (no date) $<$ http://www.iso.org/iso/home/standards_development/resources-for-technical-work/ support-for-developing-standards.htm >.

87 International Organization for Standardization, Who Develops ISO Standards? (no date) $<$ http://www.iso.org/iso/home/standards_development/who-develops-iso-standards.htm>.
} 
facto mandatory nature that heightens their relevance to market access. The recently developed ISO 22000 standards on Food Safety Management are particularly important for trade in foodstuffs. ${ }^{88}$ These standards lay down the necessary requirements for the correct implementation of all food safety management systems along the supply chain; compliance with them demonstrates an organisation's ability to control food safety hazards. ${ }^{89}$ These standards are complemented by three ISO Technical Specifications: the ISO Technical Specification 22004, which aims at giving implementation guidance to the ISO 22000:2005; ${ }^{90}$ the ISO Technical Specification 22003:2013, which defines the rules applicable for the audit and certification of a food management system; ${ }^{91}$ and ISO Technical Specifications 22002-1/4:2013, which specifies the requirements for the establishment, implementation and maintenance of prerequisite programmes to assist in controlling food safety hazards. ${ }^{92}$ Finally, ISO Standard 22005:2007, concerning traceability in the feed and food chain, establishes the general principles and basic requirements for system design and implementation..$^{93}$ This is the latest international food standard adopted by the ISO General Principles and Guidance for System Design and Development.

As is the case with the CAC standards, the number of international food standards adopted by the ISO has increased dramatically to over 1000 to date. ${ }^{94}$ This growth has led to an elevated status, which is justified by the direct

${ }^{88}$ International Organization for Standardization, ISO 22000, Food Safety Management Systems - Requirements for Any Organization on the Food Chain (no date) <http://www.iso. org/iso/ home/store/catalogue_tc/catalogue_detail.htm?csnumber=35466>.

${ }^{89}$ They include feed producers, primary producers, food manufacturers, transport and storage operators, retail and food service establishments, producers of equipment, packaging material, additives and ingredients.

90 International Organization for Standardization, ISO Technical Specification ISO/TS 22004:2005 - Food Safety Management Systems: Guidance on the Application of ISO 22000:2005 (no date) <http://www.iso.org/iso/catalogue_detail?csnumber=39835>.

91 International Organization for Standardization, ISO Technical Specification ISO/TS 22003:2013, Food Safety Management Systems: Requirements for Bodies providing Audit and Certification of Food Safety Management Systems (no date) <http://www.iso.org /iso/home/store/catalogue_tc/catalogue_detail.htm?csnumber=60605>.

${ }^{92}$ International Organization for Standardization , ISO Technical Specification ISO/TS 220021/4:2009, Prerequisites Programmes for Food Safety: Catering, Food Manufacturing, Farming and Food Packaging Manufacturing (no date) <http://www.iso.org/iso/home/store/ catalogue_tc/catalogue_detail.htm?csnumber $=44001>$.

${ }^{93}$ International Organization for Standardization, ISO Technical Specification ISO 22005: 2007, Traceability in the Feed and Food Chain: General Principles and Basic Requirements for System Design and Implementation (no date) <http://www.iso.org/iso/home/store/ catalogue_tc/catalogue_detail.htm?csnumber=36297>.

${ }^{94}$ International Organization for Standardization, ISO Standards and Food: Quality and Safety from Farm to Fork (January 2012) <http://www.iso.org/iso/iso_and_food.pdf>. 
recognition of the ISO as a relevant international standard-setting organisation in the TBT Agreement. Indeed, according to Article 4.1 of the TBT Agreement, WTO Members must ensure that their national standard bodies comply with the Code of Good Practice, which is in turn an ISO product. ${ }^{95}$ The resulting reinforcement of legitimacy is also evident in the recent amendment of the ISO Statutes, establishing that only national standards bodies can become members. Given that international standards are effective only after being implemented at their respective domestic levels, the impact of national standards bodies in ensuring harmonisation is evident.

\section{The Curious Case of Private Food Standards AND WTO LAW}

The last decade has seen an increase in the use of standards solely designed and adopted by private players. Much has been written about the challenges that they pose for international trade. ${ }^{96}$ These standards are developed not by domestic policy-makers or international organisations, but are primarily designed by large supermarket chains in a bid to ensure the quality and safety of their retail products. ${ }^{97}$ The contractual obligation owed by the supplier to comply with a set of specific standards undoubtedly has a binding effect from the private law perspective. In developing a specified set of (food) standards, suppliers have to commit to complying with them in order to avoid a breach of contract. It has therefore been claimed that their voluntary nature becomes $d e$ facto mandatory. ${ }^{98}$

\footnotetext{
${ }^{95}$ Agreement on Technical Barriers to Trade, opened for signature 12 April 1979, 1186 UNTS 276 (entered into force 1 January 1980) annex 3 ('Code of Good Practice for the Preparation, Adoption and Application of Standards').

${ }^{96}$ Organisation for Economic Co-operation and Development, 'Final Report on Private Standards and the Shaping of Agro-Food Systems', Paris (2006). See also: Steve Jaffe and Olivier Masakure, 'Strategic Use of Private Standards to Enhance International Competitiveness: Vegetable Exports from Kenya and Elsewhere' (2005) 30 Food Policy 316-33; Organisation for Economic Co-operation and Development, 'Private Standards Schemes and Developing Countries Access to Global Value Chains: Challenges and Opportunities Emerging from Four Case Studies', AGR/CA/APM(2006)20/final, Paris, (2007); Tetty Havinga, 'Private Regulation of Food Safety by Supermarkets' (2006) 28(4) Law and Policy, 515-33; Lawrence Busch, 'The Moral Economic of Grades and Standards' (2000) 16 Journal of Rural Studies 273-83.

${ }^{97}$ Doris Fuchs, Agni Kalfagianni and Tetty Havinga, 'Actors in Private Food Governance: The Legitimacy of Retail Standards and Multi stakeholders Initiatives with Civil Society Participation' (2009) 28 Agricultural Human Values 353-67.

${ }^{98}$ Ibid; Spencer Henson and Thomas Reardon, 'Private Agri-Food Standards: Implications for Food Policy and the Agri-Food System’ (2005) 30 Food Policy 241-53.
} 
From a public international law perspective, however the proliferation of private voluntary food standards poses important challenges to the correct application of the WTO rules in particular. This is so due to the assumed fact that private parties, such as supermarket chains, are not subjects of international law and therefore obligations arising out of the Marrakesh Agreements do not apply to them. Jurisdictional objections aside, trade concerns have been raised in WTO fora about the implications of private parties imposing, in their crossborder contracts, compliance with voluntary standards that go beyond the level of protection offered by domestic, WTO-compliant regulation. The question that remains open is whether the WTO Agreements, particularly the SPS Agreement, have sufficient flexibility to address the legal implications of private voluntary safety standards and so diminish the trade-distorting effects, such as compliance costs and import discrimination, ${ }^{99}$ attributed to them.

\section{A Private Food Standard-Setting Entities}

It has been claimed that the recent development of standard setting by private entities has both positive and negative implications for international trade. Such standards are trade-enhancing because they can contribute to product differentiation, improve quality and safety, disseminate modern and efficient technologies, and ultimately guarantee market access. They are trade-distorting because they disguise protectionist measures, artificially fragment markets, impose unreasonable requirements on suppliers, and thus restrict market access. Five key private standard-setting bodies have been identified as the major driving forces behind the proliferation of private food safety standards: the Global Food Safety Initiative ('GFSI'), the Global Partnership for Good Agricultural Practices ('GlobalGAP'), Safe Quality Food ('SQF'), the International Food Standard ('IFS') and the British Retail Consortium ('BRC').

The GFSI was initiated in 2000 by a group of international retailers in order to agree on a globally accepted food safety benchmark. It sets baseline requirements for food safety standards and aims to improve efficiency costs throughout the food supply chain. Its central aim is to strengthen consumer confidence in food bought in retail outlets. ${ }^{100}$

GlobalGAP was first developed in 1997 as EurepGAP by a group of European retailers; since 2007 it has been known as GlobalGAP. Its standards initially applied to fruit and vegetables only, but now also cover meat products and fish

\footnotetext{
${ }^{99}$ Steven Jaffe and Spencer Henson, Standards and Agro-Food Exports from Developing Countries: Rebalancing the Debate (World Bank Policy Research Paper 3348, June 2004) 3.

${ }^{100}$ Fuchs, Kalfagianni and Havinga, above n 97.
} 
from aquaculture. Compliance with its standards requires the completion of a checklist consisting of 254 questions to obtain certification.

SQF was developed in 1994 by the Western Australian Department of Agriculture and sold to the US in 2003. It is a food safety and quality program for primary production and for food manufacturing and distribution. It is now owned by the US Food Marketing Institute, whose membership represents three-quarters of American food retailers and 200 companies from over 50 countries. ${ }^{101}$

The IFS was initiated in 2002 by German food retailers. A year later the French Food Retailers' association joined, followed by the Italian Food Retailers' Association. Retailers from Austria, Poland, Spain and Switzerland also adopted the IFS food safety standard. This standard deals with the processing of food and contains 250 requirements divided into the areas of production processes, management responsibility, quality management systems, resource management, measurements and improvements, and audit protocol. ${ }^{102}$

The BRC was created in 1998 to evaluate the manufacturing of retailers' own brand products. It delineates more than 250 requirements including comprehensive norms for food safety and quality schemes, products and process management, and the personnel's personal hygiene. ${ }^{103}$

The number of what are considered private standard-setting entities continues to grow. While the line between entities embedded in public or private law is often blurred, this Part does not attempt to examine the legal nature of the standard-setting entities. Rather, it focuses on the products produced, that is, the private food standard, which is currently under the scrutiny of the SPS Committee.

\section{B Discussion of Private Standards in the SPS Committee}

The private voluntary food standards described above have raised concerns among the governments of least developing and developing nations within the WTO. Although private food standards extend to both quality and safety, it is safety standards which have received the most attention. In particular, the SPS Committee was called upon to establish a working group in order to tackle the

\footnotetext{
${ }^{101}$ Ibid.

102 Ibid.

${ }^{103}$ Ibid.
} 
issue of whether private safety standards fall within the scope of the SPS Agreement.

The first concerns were raised by St Vincent and the Grenadines in 2005, whose government complained about the additional requirements set by EurepGap for exporting bananas to the United Kingdom. ${ }^{104}$ Supported, among others, by Ecuador ${ }^{105}$ and Argentina, ${ }^{106}$ St Vincent and the Grenadines complained that these additional private food standards are more stringent than the public mandatory food standards that are in place.

As a response to these concerns, the SPS Committee agreed to undertake a three-step comparative study on the effects of private SPS standards. As a first step, the Secretariat circulated a questionnaire about SPS-related private standards in 2008. ${ }^{107}$ A second step saw the circulation in 2009 of a descriptive report summarising the information contained in the 40 responses obtained from 22 Members. ${ }^{108}$ As the third and last step the Secretariat then prepared an analytical report identifying possible actions. ${ }^{109}$ The proposed recommendations were amended after a discussion between the ad hoc working group on private standards and the SPS Committee, and a revised version of the recommendations was circulated in March 2010. ${ }^{110}$ After the ad hoc working group meeting, a second revised version of the recommendations was circulated. ${ }^{111}$ A couple of months later, a third revision of the recommendation was issued. ${ }^{112}$

\footnotetext{
${ }^{104}$ Private Industry Standards, WTO Doc G/SPS/GEN/766 (28 February 2007), Communication from Saint Vincent and the Grenadines.

105 Private and Commercial Standards, WTO Doc G/SPS/GEN/792 (5 July 2007), Statement by Ecuador at the Meeting of 27-28 June 2007.

${ }^{106}$ Private Standards and the SPS Agreement, WTO Doc G/SPS/W/746 (24 January 2007), Note by the Secretariat.

107 Questionnaire on SPS-Related Private Standards, WTO Doc G/SPS/W/232 (8 December 2008), Note by the Secretariat.

${ }^{108}$ Effects of SPS-Related Private Standards: Descriptive Report, WTO Doc G/SPS/GEN/932 (15 June 2009), Note by the Secretariat.

109 Possible Actions for the SPS Committee Regarding Private SPS Standards, WTO Doc G/SPS/W/247 (20 October 2009), Note by the Secretariat.

110 Possible Actions for the SPS Committee regarding Private SPS Standards, WTO Doc G/SPS/W/247/Rev.1 (5 March 2010), Note by the Secretariat - Revision No.1.

${ }^{111}$ Possible Actions for the SPS Committee Regarding SPS-Related Private Standards, WTO Doc G/SPS/W/247/Rev.2 (15 June 2010), Note by the Secretariat - Revision No. 2.

112 Possible Actions for the SPS Committee Regarding SPS-Related Private Standards, WTO Doc G/SPS/W/247/Rev.3 (11 October 2010), Note by the Secretariat - Revision No. 3.
} 
In March 2011, six actions were proposed to the SPS Committee by the ad hoc working group on SPS-related private standards. ${ }^{113}$ At its meeting on 20-31 March 2011, the SPS Committee adopted five of the six actions put forward:

Action 1: The SPS Committee should develop a working definition of SPSrelated private standards and limit any discussions to these....

Action 2: The SPS Committee should regularly inform Codex, OIE and IPPC regarding relevant developments in its considerations of SPS-related private standards, and should invite these organizations to likewise regularly inform the SPS Committee of relevant developments in their respective bodies. ...

Action 3: The SPS Committee invites the Secretariat to inform the Committee on developments in other WTO fora which could be of relevance for its discussions on SPS-related private standards. ...

Action 4: Members are encouraged to communicate with entities involved in SPS-related private standards in their territories to sensitize them to the issues raised in the SPS Committee and underline the importance of international standards established by the Codex, OIE and IPPC. ...

Action 5: The SPS Committee should explore the possibility of working with the Codex, OIE and IPPC to support the development and/or dissemination of informative materials underlining the importance of international SPS standards. ${ }^{114}$

Since then, the SPS Committee has been working on addressing Action 1, namely establishing a working definition of SPS-related private standards. ${ }^{115}$ While New Zealand and China have managed to produce a draft definition of private SPS standards, ${ }^{116}$ Members remain deadlocked. As of March 2014, ${ }^{117}$ the SPS Committee has entrusted the Secretariat with the compilation of relevant information on the definition of private standards within other international standard-setting bodies. This data was discussed in the SPS

\footnotetext{
${ }^{113}$ Report of the ad hoc Working Group on SPS-Related Private Standards to the SPS Committee, WTO Doc G/SPS/W/256 (3 March 2011).

${ }^{114}$ Actions Regarding SPS-Related Private Standards, WTO Doc G/SPS/55 (6 April 2011), Decision of the Committee 1-3.

115 'Proposed Working Definition of SPS-Related Private Standards', WTO Doc G/SPS/W/265 (6 March 2012), Note by the Secretariat; 'Proposed Working Definition of SPS-related Private Standards', WTO Doc G/SPS/W/265/Rev1 (26 June 2012), Note by the Secretariat - Revision No 1; 'Proposed Working Definition of SPS-related Private Standards', WTO Doc G/SPS/W/265/Rev.2, (28 September 2012), Note by the Secretariat - Revision No 2.

116 'Report of the Co-Stewards of the Private Standards E-Working Group on Action 1', WTO Doc G/SPS/W/276 (18 March 2014), Submission by the co-stewards of the e-working group. ${ }^{117}$ Ibid.
} 
Committee's formal meeting in July 2014, where Argentina referred to additional definitions established by the OIE and the CAC, while Canada pointed out the current OECD efforts to draft a definition of private standards. ${ }^{118}$ The Committee agreed to consider these new developments before circulating a report on a 'compromise working definition of an SPS-related private standard'. 119

\section{Outlook}

It is to be expected that private standard-setting organisations will become legally relevant for WTO purposes, given the importance in international trade that they have acquired recently. ${ }^{120}$ It is argued here that a test analogous to the relevant-standard test as introduced in the context of Article 2.4 of the TBT Agreement in US - Tuna II (Mexico) must be used to determine whether the SPS Agreement is applicable to private food safety standards. If this occurs, all SPS measures - public and private - will be covered by the SPS Agreement, thus acquiring a higher level of global legitimacy.

Although a further increase in the use of private food standards is feasible and not disputed here, national policy will determine the extent of their implications for international trade. It can therefore be predicted that, based on the level of domestic legislative activity, public standards will overlap with and eventually marginalise the use of private food standards. This line of argumentation is further supported by the discussions within the SPS Committee.

In any event, public standards will still be necessary to correct market failures associated with information asymmetries or consumption externalities. They will therefore continue to play a key role in establishing a minimum level of protection to ensure the placing on the market of safe food and to prevent fraud. ${ }^{121}$

Much effort has been put into bringing forward the agenda within the SPS Committee. Regrettably, the progress made to date has been minimal. It remains to be seen whether a private SPS measure will become the basis of a

\footnotetext{
118 'Existing Definitions of Private Standards in Other International Organizations', WTO Doc G/SPS/GEN/1334 (18 June 2014), Note by the Secretariat.

119 'Existing Definitions of Private Standards in Other International Organizations', WTO Doc G/SPS/GEN/1334/Rev.1 (5 August 2014), Note by the Secretariat - Revision No 1 [1.6].

${ }^{120}$ Jaffe and Masakure, above 96, 317; Havinga, above 96, 516; Busch, above 96, 274.

${ }^{121}$ Gary Smith, 'Interaction of Public and Private Standards in the Food Chain' (OECD Food, Agriculture and Fisheries Working Paper $\mathrm{Nr}$ 15, OECD Publishing 2009) AGR/CA/APM(2006)21/final, [10].
} 
challenge before the WTO Dispute Settlement System. Until then, we are merely speculating. Ultimately, party autonomy to contract is an inherently private choice that may as well be the unintended effect of liberalised trade.

\section{CONCLUSION}

Although voluntary in nature, food standards can be given a legally binding character by virtue of the presumption of compliance implicit in the WTO Agreements. The legal concept of the 'international standard' captured by the TBT Agreement provides a legal base from which to assess the conformity of domestic food measures with WTO members' international law obligations. In particular, Article 2.4 of the TBT Agreement and its judicial interpretations offer a benchmark against which the legality of prima facie protectionist measures must be tested.

Based on four leading cases, the WTO Appellate Body conceptualised 'relevant international standards' as those pertinent standards designed by recognised standardisation bodies with open membership for WTO members. A three-step test was identified, according to which 1) it must be apparent that the international standard was used as a principal constituent or fundamental principle in enacting that technical regulation, 2) there must be a very strong and close relationship between the standard invoked and the regulation enacted and 3) there must be a lack of contradiction between the former and the latter. Significantly, the WTO Appellate Body held in an argumentum e contrario that WTO Members have a right not to base their regulations on relevant international standards in cases when its use would lead to an inappropriate or ineffective level of protection for the fulfillment of its legitimate objectives.

The WTO obligation to base domestic measures on relevant international standards, as well as the direct reference about international standards in WTO agreements, has contributed to the increasing importance of standard-setting bodies in international food trade. This development reflects the role played by standard-setting bodies in the creation of new forms of food governance. Likewise, the importance given to membership openness in international standard-setting bodies, as defined by the Appellate Body in US - Tuna II (Мехiсо), has highlighted the need to assess membership mechanisms. While this aspect is undisputed in so far as the CAC is concerned, the legal status of ISO membership was rather uncertain until recently. After the amendment of its Statutes in 2012, whereby individuals and companies are no longer eligible for ISO membership, the balance between WTO case law and legitimacy principles was able to be restored. 
Although the definition of the term 'international standard' is still far from precise, the interpretative path developed by the WTO Appellate Body offers increased certainty as to the extent to which the relevant stakeholders and governments may rely on voluntary food standards in order to comply with international law obligations. It remains to be seen whether pending WTO cases prove the hypothesis posited here, whereby WTO law provides sufficient flexibilities to address the legal challenges posed by standard-setting bodies embedded in private law. 